\title{
Recent insights how combined inhibition of immuno/proteasome subunits enables therapeutic efficacy
}

\author{
Michael Basler $0^{1,2} \cdot$ Marcus Groettrup ${ }^{1,2}$
}

\begin{abstract}
The proteasome is a multicatalytic protease in the cytosol and nucleus of all eukaryotic cells that controls numerous cellular processes through regulated protein degradation. Proteasome inhibitors have significantly improved the survival of multiple myeloma patients. However, clinically approved proteasome inhibitors have failed to show efficacy against solid tumors, neither alone nor in combination with other therapies. Targeting the immunoproteasome with selective inhibitors has been therapeutically effective in preclinical models for several autoimmune diseases and colon cancer. Moreover, immunoproteasome inhibitors prevented the chronic rejection of allogeneic organ transplants. In recent years, it has become apparent that inhibition of one single active center of the proteasome is insufficient to achieve therapeutic benefits. In this review we summarize the latest insights how targeting multiple catalytically active proteasome subunits can interfere with disease progression in autoimmunity, growth of solid tumors, and allograft rejection.
\end{abstract}

\section{Introduction}

The proteasome is the main protease in the cytosol and nucleus of all eukaryotic cells and exerts numerous essential regulatory functions in nearly all cell biological pathways. The $26 \mathrm{~S}$ proteasome degrades poly-ubiquitylated protein substrates and consists of a $19 \mathrm{~S}$ regulator bearing ubiquitin receptors and an ATPase ring in charge of protein unfolding as well as a $20 \mathrm{~S}$ proteolytic core complex. Structurally, the $20 \mathrm{~S}$ proteasome core particle consists of four stacked rings, each consisting of seven subunits. The inner two rings of the constitutive proteasome are composed of $\beta$-subunits and bear the catalytically active subunits proteasome subunit beta (PSMB)6 ( $\beta 1 \mathrm{c})$, PSMB7 $(\beta 2 \mathrm{c})$, and PSMB5 ( $\beta 5 \mathrm{c})$ [1]. These three proteolytically active subunits are responsible for at least three peptidase activities: caspase-like (exerted by $\beta 1 \mathrm{c}$ ), trypsin-like (exerted by $\beta 2 \mathrm{c}$ ), and chymotrypsin-like (exerted by $\beta 5 \mathrm{c}$ ) activities. Immunoproteasomes are formed by replacing the standard

$\triangle$ Michael Basler

Michael.Basler@uni-konstanz.de

1 Division of Immunology, Department of Biology, University of Konstanz, D-78457 Konstanz, Germany

2 Biotechnology Institute Thurgau at the University of Konstanz (BITg), CH-8280 Kreuzlingen, Switzerland proteasome subunits $\beta 1 \mathrm{c}, \beta 2 \mathrm{c}$, and $\beta 5 \mathrm{c}$ with the immunoproteasome subunits low molecular mass polypeptide (LMP) 2 ( $\beta 1$ i; PSMB9), multicatalytic endopeptidase complex-like (MECL)-1 ( $\beta 2 \mathrm{i}$; PSMB10), and LMP7 ( $\beta 5 \mathrm{i}$; PSMB8) in cells of hematopoietic origin and in most other tissues after the stimulation with the pro-inflammatory cytokine interferon (IFN)- $\gamma$. These exchanges alter the cleavage-specificity of the $20 \mathrm{~S}$ proteasome. In immunoproteasomes the caspase-like activity, exerted by $\beta 1 \mathrm{c}$ in standard proteasomes, is strongly reduced, whereas the chymotrypsin-like activity is enhanced. Whereas B cells, T cells, and monocytes mainly express immunoproteasomes [2,3], immunoproteasome expression in tumors varies depending on cancer type and differentiation status. Furthermore, mixed structures consisting of standardand immunoproteasome subunits have been described [4].

Due to the role of proteasomes in the regulation of numerous cellular processes, inhibition of the proteasome is an attractive strategy to anticancer therapy. Several proteasome inhibitors of different structural classes have been described in the last three decades [5-8]. Based on whether or not they form a covalent bond with the active site threonine, these inhibitors can be divided into two large groups (covalent inhibitors, noncovalent inhibitors), which can be further subdivided into structural classes, like aldehydes, boronates, epoxyketones, $\alpha$ ketoaldehyde, $\beta$-lactones, vinyl-sulfones, syrbactins, and oxathiazolones. The reversibly binding peptide boronate proteasome inhibitor bortezomib (Velcade ${ }^{\circledast}$ ) (Fig. 1a), which targets 


\section{A Bortezomib}<smiles>CC(C)CC(CC(=O)CN(Cc1ccccc1)C(=O)c1ccccn1)C(C)C</smiles>

D ONX 0914

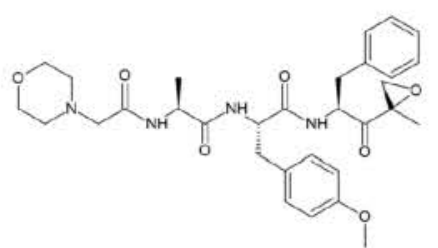

\section{G Luminmycin A}

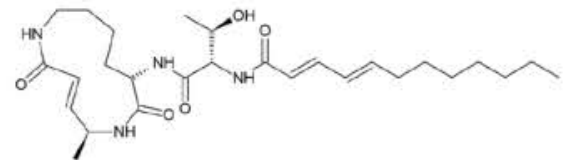

B Carfilzomib<smiles>CC(C)C[C@H](NC(=O)[C@H](CCc1ccccc1)NC(=O)CN1CCOCC1)C(=O)N[C@@H](Cc1ccccc1)C(=O)N[C@H]1CC(C)C2O[C@]2(C)C1=O</smiles>

E Marizomib

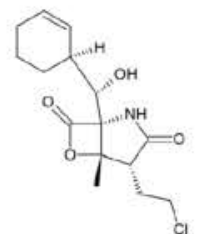

C Ixazomib<smiles>CC(C)CC(C)CC(=O)CCC(=O)c1cc(Cl)ccc1Cl</smiles>

\section{H Glidobactin C}

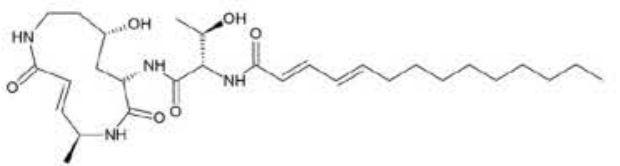

\section{PRN1126}

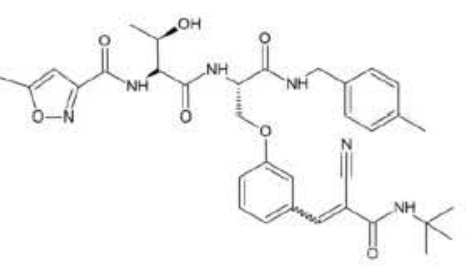

J LU-001i

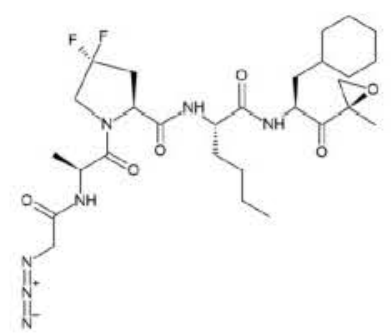

K ML604440<smiles>CC(C)C[C@H](NC(=O)C(C)(C)NC(=O)c1ccccc1C(F)(F)F)B(O)O</smiles>

L KZR-504

M Compound 10 Ref. ${ }^{\text {[96] }}$

N Compound 8 Ref. [96]<smiles>CC12CC(NC(=O)[C@H](CO)NC(=O)c3cccc(=O)[nH]3)C(=O)C(C)(O1)c1ccccc12</smiles>

O KZR-616

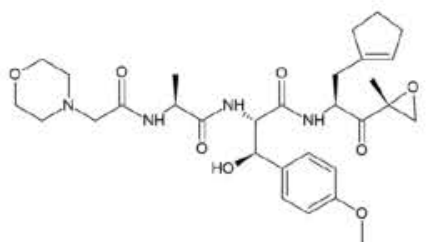

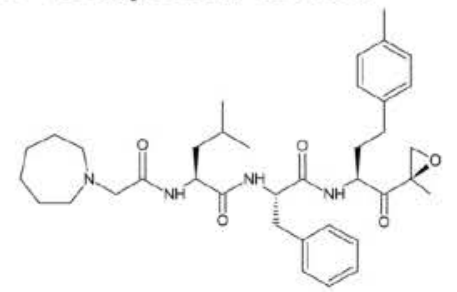

P LU-005i

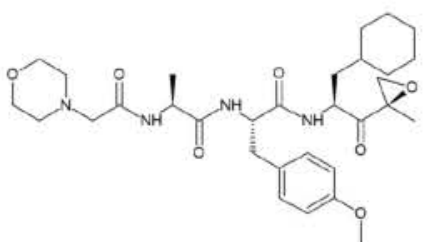

Q DPLG3

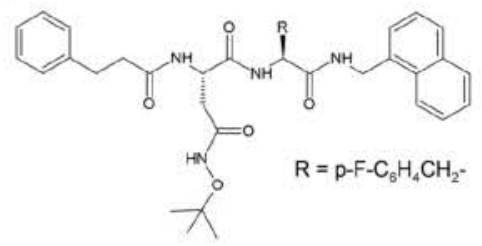

Fig. 1 Chemical structures of proteasome inhibitors described in this review. Chemical structures of (a) bortezomib, (b) carfilzomib, (c) ixazomib, (d) ONX 0914, (e) marizomib, (f) glidobactin A, (g) luminmycin A, (h) glidobactin C, (i) PRN1126, (j) LU-001i, (k) ML604440, (I) KZR-504, (m) compound 10 Ref. [96], (n) compound 8 Ref. [96], o) KZR-616, (p) LU-005i, and (q) DPLG3 are shown. 
both the constitutive proteasome and immunoproteasome, is the first clinically approved proteasome inhibitor for relapsed and/or refractory myeloma and mantle cell lymphoma [9]. To overcome intrinsic or acquired resistance and off-target toxicity of bortezomib, the irreversibly binding peptide epoxyketonebased proteasome inhibitor carfilzomib (Kyprolis ${ }^{\star}$ ) (Fig. 1b) has been developed [10]. Later, the boronate-based, orally available compound ixazomib (Ninlaro ${ }^{\star}$ ) (Fig. 1c) was approved for treatment of relapsed/refractory multiple myeloma. Its faster off-rate for proteasome binding than bortezomib allows to associate and dissociate with multiple proteasomes, thus, leading to a broader tissue distribution [11]. In addition to cancer, proteasome inhibitors were also evaluated in autoimmune diseases [12,13] and transplantation medicine [14-16] in humans. Although proteasome inhibitor treatment might have had some positive effects in these trials the rather severe side effects of proteasome inhibition, such as anemia, thrombocytopenia, and neutropenia, limits its therapeutic applicability for autoimmune diseases and interference with transplant rejection.

Immunoproteasomes are constitutively expressed in hematopoietic cells, induced in cells stimulated with IFN- $\gamma$, and upregulated in certain cancers. Therefore, immunoproteasome inhibitors can be more selective and have fewer toxic side effects than standard proteasome inhibitors. Immunoproteasome inhibitors have been very effective in dampening the activation of lymphocytes [2, 17, 18], in altering macrophage polarization [19], in reducing secretion of pro-inflammatory cytokines [20-25], and in dampening T helper $(\mathrm{Th})_{17}$ differentiation [20, 24-28]. Furthermore, the immunoproteasome has been shown to be a promising drug target in several preclinical disease models for autoimmunity [20-22, 24, 28-33], for brain inflammations $[34,35]$, colitis-associated cancers [26, 36], angiogenesis [37], viral myocarditis [38], acute kidney injury [39], ischemic stroke [25], preterm birth [40], abdominal aortic aneurysm [41], atherosclerosis [42], cardiac remodeling [43], Alzheimers's disease [44, 45], and organ transplantation [17, 46, 47]. Hence, immunoproteasome inhibitors might emerge as a new treatment option for several diseases (summarized in Table 1) with reduced side effects compared to inhibitors targeting the standard proteasome.

Indeed, the peptide-ketoepoxide immunoproteasome inhibitor ONX 0914 (formerly named PR-957) (Fig. 1d) has been associated with reduced neurotoxicity compared to bortezomib [48].

\section{Proteasome co-inhibition in solid tumors}

Many proteasome target proteins, such as tumor suppressor protein p53, cyclins, cyclin dependent kinase inhibitor $\mathrm{p} 27$,

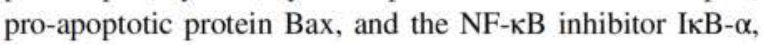

are involved in carcinogenesis and cancer survival. Proteasome inhibition in multiple myeloma causes a toxic build-up of proteins leading to apoptosis [49]. Initially, experiments performed in yeast identified the $\beta 5$ subunit of the proteasome as the rate-limiting subunit in proteasomal protein degradation [50, 51]. Consequently, proteasome inhibitors were designed to target the $\beta 5$ subunit. However, targeting only $\beta 5$ has little effects on protein degradation [52]. More than $50 \%$ inhibition of protein degradation is achieved only when both $\beta 5$ and either $\beta 1$ or $\beta 2$ sites are inhibited [53, 54]. Hence, the $\beta 1$ and $\beta 2$ sites should be considered as co-targets of anticancer drugs. Indeed, coinhibition of either trypsin-like and/or caspase-like sites together with $\beta 5$ inhibition is needed to achieve maximal cytotoxicity in multiple myeloma cell lines [52, 55-58]. Bortezomib targets the $\beta 5$ and $\beta 1$ activity, but not the $\beta 2 \mathrm{c}$ activity of the proteasome [9, 59]. Carfilzomib displays greater specificity than bortezomib for $\beta 5$ activity relative to $\beta 1$ activity [60]. However, greater occupancy of multiple 20S subunits was associated with an increased likelihood of achieving a clinical response at higher carfilzomib doses in multiple myeloma patients, indicating that targeting multiple proteasome sites is beneficial [61]. Due to its success in multiple myeloma therapy, bortezomib was used in many clinical studies to investigate its potential as an antitumor agent in different solid tumors, like f.i. lung cancer, prostate cancer, and breast cancer (summarized in [62]). However, bortezomib as monotherapy or in combination with other therapies has not enabled a clinical benefit in patients with solid tumors. Although bortezomib is effective in the treatment of hematological malignancies, the reason for the unresponsiveness in solid cancers remains elusive. In vitro, cell lines derived from solid tumor cells are as sensitive to proteasome inhibitors as multiple myeloma cells [9]. Pharmacodynamics data obtained in clinical trials show that bortezomib equally inhibits proteasomes in solid tumors and blood, suggesting poor tumoral penetration not to be the reason for the lack of activity in solid tumors in vivo [63].

A possible explanation for the lack of response to proteasome inhibitors in solid tumors is insufficient potency. Indeed, Kisselev and co-workers showed that inhibiting a second site of the proteasome, particularly the $\beta 2$-site, sensitized triple-negative breast cancer cell lines to bortezomib and carfilzomib [64]. Like other solid tumors, bortezomib was not effective in patients suffering from breast cancer $[63,65]$. However, in vitro, many different triplenegative breast cancer cell lines were more sensitive than multiple myeloma cells to treatment with bortezomib under identical conditions resembling clinically achievable proteasome inhibition [64]. Interestingly, the viability correlated not with inhibition of the $\beta 5$ site, but with the onset of inhibition of $\beta 1$. Greater cytotoxicity was usually observed only at concentrations at which the $\beta 1$ and $\beta 2$ sites were at 
Table 1 Table of diseases investigated in preclinical models with immunoproteasome-selective inhibitors.

\begin{tabular}{|c|c|c|c|c|c|}
\hline Disease & Preclinical model & Immunoproteasome inhibitor & Treatment & Effect & Citation \\
\hline \multirow[t]{2}{*}{ Rheumatoid arthritis } & Collagen antibody-induced arthritis & ONX 0914 & Therapeutic & Amelioration of disease symptoms & [20] \\
\hline & Collagen-induced arthritis & ONX 0914 & Therapeutic & Amelioration of disease symptoms & [20] \\
\hline Type I diabetes & LCMV RIP-GP model & ONX 0914 & Preventive & Reduction in blood glucose level & [20] \\
\hline \multirow[t]{2}{*}{ Colitis } & DSS-induced colitis & ONX 0914 & Preventive & Amelioration of disease symptoms & [21] \\
\hline & DSS-induced colitis & DPLG3 & Preventive & Amelioration of disease symptoms & [33] \\
\hline \multirow{2}{*}{$\begin{array}{l}\text { Systemic lupus } \\
\text { erythematodes }\end{array}$} & Lupus prone MRL/pr mice & ONX 0914 & Preventive & Prevents disease progression & [29] \\
\hline & Lupus prone NZB/W mice & ONX 0914 & Preventive & Prevents disease progression & [29] \\
\hline \multirow[t]{2}{*}{ Hashimoto's thyroiditis } & Sodium iodide injection into NOD-H2 ${ }^{\mathrm{h4}}$ mice & ONX 0914 & Preventive & Reduced thyroiditis scores & [30] \\
\hline & Sodium iodide injection into NOD- $\mathrm{H} 2^{\mathrm{h} 4}$ mice & ONX 0914 & Therapeutic & Reduced thyroiditis scores & [30] \\
\hline Graves' hyperthyroidism & $\begin{array}{l}\text { Immunization of susceptible BALB/c mice with Ad- } \\
\text { TSHR289 }\end{array}$ & ONX 0914 & Preventive & No effect & [30] \\
\hline \multirow[t]{5}{*}{ Multiple sclerosis } & $\mathrm{MOG}_{35-55}$ induced $\mathrm{EAE}$ & ONX 0914 & Preventive & Strongly delays disease induction & [22] \\
\hline & & ONX 0914 & Therapeutic & Ameliorates disease progression & [22] \\
\hline & Transfer of $M O_{35-55}$ reactive $T$ cells & ONX 0914 & Preventive & Reduction of disease symptoms & [22] \\
\hline & PLP $_{139-151 \text {-induced EAE }}$ & ONX 0914 & Therapeutic & $\begin{array}{l}\text { Prevents disease progression and } \\
\text { relapse }\end{array}$ & [22] \\
\hline & Transfer of PLP $P_{139-151}$ reactive $T$ cells & ONX 0914 & Therapeutic & $\begin{array}{l}\text { Prevents disease progression and } \\
\text { relapse }\end{array}$ & [22] \\
\hline Neuritis & $\begin{array}{l}\text { Immunization with the neuritogenic synthetic P0 peptide } \\
180-199 \text { in rats }\end{array}$ & ONX 0914 & Preventive & Reduced clinical score & [31] \\
\hline Myasthenia gravis & Immunization of rats with the R97-116 peptide & ONX 0914 & Preventive & Reduced clinical score & [32] \\
\hline \multirow[t]{2}{*}{ Autoimmune myocarditis } & Cardiac troponin I-directed autoimmune myocarditis & ONX 0914 & Preventive & $\begin{array}{l}\text { Diminished troponin I autoimmune } \\
\text { myocarditis }\end{array}$ & {$[118]$} \\
\hline & Cardiac troponin I-directed autoimmune myocarditis & ONX 0914 & Therapeutic & $\begin{array}{l}\text { Diminished troponin I autoimmune } \\
\text { myocarditis }\end{array}$ & [118] \\
\hline Kidney transplantation & $\begin{array}{l}\text { Chronic rejection of kidneys transplanted from Fischer to } \\
\text { allogeneic Lewis rats }\end{array}$ & ONX 0914 & $\begin{array}{l}\text { Starting after } \\
\text { transplantation }\end{array}$ & Survival of grafted kidney & {$[46,47]$} \\
\hline Heart transplantation & $\begin{array}{l}\text { BALB/c hearts transplanted into fully allogeneic C57BL } \\
6 \text { recipients }\end{array}$ & DPLG3 & $\begin{array}{l}\text { Starting after } \\
\text { transplantation }\end{array}$ & Prolonged graft survival & [17] \\
\hline Preterm birth & LPS-induced preterm birth in mice & ONX 0914 & $\begin{array}{l}\text { Co-application of LPS } \\
\text { and ONX } 0914\end{array}$ & Reduced inflammation & [40] \\
\hline \multirow[t]{3}{*}{ Alzheimer's disease (AD) } & LPS-induced mouse model of neuroinflammation & $\begin{array}{l}\text { YU102 (selective for LMP2 } \\
\text { and } \beta 1 \mathrm{c} \text { ) }\end{array}$ & 5 days post LPS & Improved cognitive function & [44] \\
\hline & & PR-924 (LMP7 selective) & Preventive & $\begin{array}{l}\text { Could not be assessed due to strong } \\
\text { toxicity in this model }\end{array}$ & [44] \\
\hline & & $\begin{array}{l}\text { YU102 (selective for LMP2 } \\
\text { and } \beta 1 \mathrm{c} \text { ) }\end{array}$ & $\begin{array}{l}\text { Starting at the age of } \\
9 \text { months }\end{array}$ & $\begin{array}{l}\text { Ameliorates AD-related cognitive } \\
\text { impairment }\end{array}$ & [44] \\
\hline
\end{tabular}


Table 1 (continued)

\begin{tabular}{|c|c|c|c|c|c|}
\hline Disease & Preclinical model & Immunoproteasome inhibitor & Treatment & Effect & Citation \\
\hline & $\begin{array}{l}\text { Transgenic mouse model } \mathrm{Tg} 2576 \text {, which expresses } \\
\text { human amyloid precursor protein (APP) with the } \\
\text { Swedish double mutation (KM670/671NL) }\end{array}$ & $\begin{array}{l}\text { DB-310 (LMP2 selective } \\
\text { inhibitor) }\end{array}$ & $\begin{array}{l}\text { Starting at the age of } \\
9 \text { months }\end{array}$ & Ameliorates cognitive deficits & [45] \\
\hline Ischemic stroke & Middle cerebral artery occlusion (MCAO) in mice & ONX 0914 & After MCAO & Neuroprotective effects & [25] \\
\hline Cardiac remodeling & DOCA-salt cardiac remodeling mouse model & ONX 0914 & 1-day pre-surgery & $\begin{array}{l}\text { Ameliorates DOCA-salt-induced } \\
\text { cardiac remodeling and } \\
\text { dysfunction }\end{array}$ & [43] \\
\hline $\begin{array}{l}\text { Abdominal aortic } \\
\text { aneurysm (AAA) }\end{array}$ & Infusion of angiotensin II into ApoE knockout mice & ONX 0914 & $\begin{array}{l}\text { Starting at angio-tensin } \\
\text { II infusion }\end{array}$ & $\begin{array}{l}\text { Reduces AAA incidence and } \\
\text { severity }\end{array}$ & [41] \\
\hline Acute kidney injury & Kidney pedicle clamp & ONX 0914 & $\begin{array}{l}\text { Before kidney } \\
\text { pedicle clamp }\end{array}$ & $\begin{array}{l}\text { Anti-inflammation and oxidative } \\
\text { stress potency }\end{array}$ & [39] \\
\hline Atherosclerosis & $\begin{array}{l}\text { Atherogenic diet in apolipoprotein E (Apoe) } \\
\text { knockout mice }\end{array}$ & ONX 0914 & Preventive & $\begin{array}{l}\text { Suppression of diet-induced } \\
\text { atherosclerosis }\end{array}$ & [42] \\
\hline Viral meningitis & Intracranial LCMV infection & ONX 0914 & Preventive & Reduced clinical score & [35] \\
\hline \multirow[t]{3}{*}{ Viral myocarditis } & Coxsackievirus $\mathrm{B} 3$-induced myocarditis in $\mathrm{A} / \mathrm{J}$ mice & ONX 0914 & Preventive & Increased survival & [38] \\
\hline & Coxsackievirus B3-induced myocarditis in NMRI mice & ONX 0914 & Preventive & Elevated viral cytotoxicity & [119] \\
\hline & Coxsackievirus B3-induced myocarditis in NMRI mice & ONX 0914 & Therapeutic & $\begin{array}{l}\text { No anti-inflammatory effect in the } \\
\text { acute or chronic stages }\end{array}$ & [119] \\
\hline \multirow[t]{5}{*}{ Colitis-associated cancer } & Chemically induced (AOM/DSS) colon carcinogenesis & ONX 0914 & Preventive & $\begin{array}{l}\text { Reduced clinical symptoms and } \\
\text { tumor numbers }\end{array}$ & [36] \\
\hline & & ONX 0914 & Therapeutic & Reduced tumor numbers & [36] \\
\hline & & ONX 0914 & Preventive & Reduced tumor numbers & [26] \\
\hline & $\begin{array}{l}\text { Transgenic mouse model }(\mathrm{ApcMin} /+) \text { of colon } \\
\text { carcinogenesis. }\end{array}$ & ONX 0914 & Preventive & $\begin{array}{l}\text { Reduced clinical symptoms and } \\
\text { tumor numbers }\end{array}$ & [36] \\
\hline & & ONX 0914 & Therapeutic & $\begin{array}{l}\text { Reduced clinical symptoms and } \\
\text { tumor numbers }\end{array}$ & [36] \\
\hline Candida albicans infection & Intravenous injection of Candida albicans & ONX 0914 & Preventive & $\begin{array}{l}\text { Decreased survival and increased } \\
\text { candida albicans titers }\end{array}$ & [120] \\
\hline Adenovirus infection & Adenovirus type 1 infection of neonatal C57BL/6 mice & ONX 0914 & Preventive & $\begin{array}{l}\text { No effect on viral load and virus- } \\
\text { induced inflammation in the heart }\end{array}$ & [121] \\
\hline
\end{tabular}


least partially inhibited. Using site-specific proteasome inhibitors, the authors could show that selective inhibition of the $\beta 2$-site sensitized triple-negative breast cancer cells to $\beta 5$ inhibitors better than site-specific inhibition of the $\beta 1$ site. Confirming these results, genetic inactivation of the PSMB7/ $\beta 2$ gene sensitized cells to $\beta 5$ inhibition more than silencing $\beta 1$. Co-inhibition of $\beta 5$ and $\beta 2$ increased the accumulation of ubiquitylated proteins compared to $\beta 5$ inhibition alone. Interestingly, after an initial accumulation of ubiquitylated proteins in carfilzomib treated cells after $6 \mathrm{~h}$, these ubiquitin conjugates disappeared at later time points. This phenomenon went along with a recovery of $\beta 5$ activity, indicating the emergence of newly assembled proteasomes. Under homeostatic conditions, the inactive transcription factor nuclear respiratory factor $1(\mathrm{Nrfl})$ is continuously retro-translocated from the ER lumen to the cytoplasm, where it is degraded by the proteasome [66, 67]. Upon partial proteasome inhibition, Nrf1 is proteolytically processed by the aspartyl protease DNA-damage inducible 1 homolog 2 (DDI2) to a soluble, active C-terminal fragment in the cytoplasm that has transcription factor activity and translocates to the nucleus. There, it enhances the concerted transcription of genes of the ubiquitin proteasome system [68, 69]. Among others, mature $\mathrm{Nrfl}$ activates transcription of all genes encoding subunits of the $26 \mathrm{~S}$ proteasome. This results in the assembly of more $26 \mathrm{~S}$ proteasomes, which allows cells to escape the cytotoxic effects of rapidly catabolized proteasome inhibitors. Bortezomib most efficiently induces Nrf1 processing and 26S subunit expression at low concentrations that only partially block the chymotrypsin-like site and cause only a minor $(<40 \%)$ decrease in proteolysis. By contrast, higher bortezomib concentrations that completely block the $\beta 5$ site and also cause a large $(>50 \%)$ inhibition of the caspase-like site and protein breakdown, inhibit Nrfl processing leading to insoluble Nrf1 aggregation. This prevents Nrf1 nuclear entry and, thus, $26 \mathrm{~S}$ induction $[70,71]$. In the study by Weyburne et al. on breast cancer cells, carfilzomib alone or in combination with an inhibitor of the $\beta 1$ site led to $\mathrm{Nrfl}$ activation by DDI 2 cleavage and, consequently, to an upregulation of $26 \mathrm{~S}$ genes and survival of breast cancer cells [64]. In contrast, co-inhibition of the $\beta 5$ site and the $\beta 2$-site suppressed production of soluble, active Nrfl and prevented induction of proteasome genes. In line with these observations, partial knockdown of $\mathrm{Nrfl}$ increased cell death when the $\beta 5$ site alone or in combination with the $\beta 1$ was targeted, but not with $\beta 5 / \beta 2$ co-inhibition. Apart from breast cancer cells, inhibition of $\beta 2$ when combined with carfilzomib and bortezomib also sensitized cell lines originating from other solid tumor types derived from lung, renal, and ovarian cancer. Taken together, co-inhibition of $\beta 5$ and $\beta 2$ causes aggregation of $\mathrm{Nrf1}$, which blocks upregulation of proteasome genes and prevents recovery of

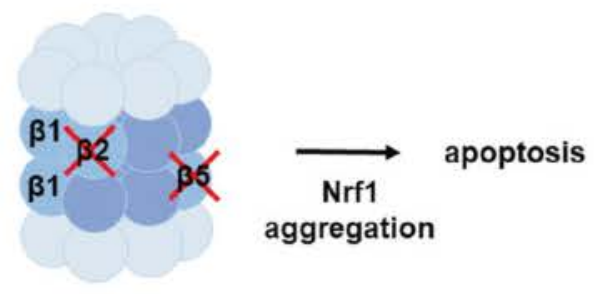

Fig. 2 Co-inhibition in solid tumors. Co-inhibition of $20 \mathrm{~S}$ proteasome subunits $\beta 5$ and $\beta 2$ causes aggregation of $\mathrm{Nrfl}$, which blocks upregulation of proteasome genes and prevents recovery of proteasome activity, and, thus, leads to cell death in solid tumors [64].

proteasome activity, and, thus, leads to cell death in solid tumors (Fig. 2).

The FDA-approved proteasome inhibitors bortezomib, ixazomib, and carfilzomib do not inhibit the $\beta 2$-site at therapeutically relevant concentrations [72]. In contrast, marizomib (Fig. 1e), a natural irreversible proteasome inhibitor purified from marine actinomycete bacteria, potently inhibits all three $20 \mathrm{~S}$ proteasome subunits and is currently in development for treatment of multiple myeloma and malignant glioma [73, 74]. Marizomib localizes to the CNS and significantly inhibits proteasome activity in the brain [75]. Targeting all subunits of the proteasome by marizomib would fulfill the requirements as delineated by Weyburne et al. to efficiently treat solid tumors [64]. The compound was studied in clinical trials in patients with metastatic solid tumors and advanced hematologic malignancies. Although marizomib can penetrate the blood-brain barrier it has a good safety profile and significant peripheral neuropathy, unlike in bortezomib regimens, was not noted. Marizomib is showing promising signs of clinical benefit and compared with the current standard-of-care agents such as thalidomide, lenalidomide, bortezomib, carfilzomib, and ixazomib, marizomib has a non-cross-reactive toxicity profile. Renal and CNS toxicity were described only at higher marizomib dose levels and infusion over shorter time periods [76-79]. The efficacy of marizomib in solid tumors was investigated in different cell lines and preclinical animal models [80-83]. Thereby, marizomib displayed superior activity to bortezomib in several solid tumor xenograft models and more potently impacted several hallmarks of cancer, including angiogenesis and invasion.

Kisselev and colleagues have demonstrated that for optimal proteasome inhibition in solid tumors and multiple myeloma, $\beta 5 \mathrm{c} / \beta 5 \mathrm{i}$ and $\beta 2 \mathrm{c} / \beta 2 \mathrm{i}$ sites have to be targeted, respectively [64, 84]. Hence, there is a strong need to develop proteasome inhibitors simultaneously targeting $\beta 5$ and $\beta 2$. Recently, a syringolin-based chemical probe was used to screen for potent inhibitors of the 20S proteasome in crude metabolite extracts from a burkholderiales bacteria strain [85]. In this screen, the previously known proteasome inhibitors glidobactin A (Fig. 1f) and luminmycin A (Fig. 
$1 \mathrm{~g})[86-88]$ as well as the novel proteasome inhibitor glidobactin C (Fig. 1h) were identified [85]. Glidobactin C displayed an unprecedented $\beta 2 / \beta 5$ co-inhibition profile with single-digit nanomolar potency. Glidobactin A and luminmycin A were poorly active in live cell experiments. However, glidobactin $\mathrm{C}$, which differs from glidobactin A only by encompassing two additional methylene groups in its acylchain, considerably inhibited substrate cleavage in live cells, suggesting that its slightly increased chain length sufficiently enhanced membrane penetration. The attractive $\beta 2 / \beta 5$ subunit co-inhibition profile in combination with its cell permeability renders glidobactin $\mathrm{C}$ a promising anticancer drug candidate. Indeed, glidobactin $\mathrm{C}$ induced accumulation of ubiquitin conjugates in a fibrosarcoma cell line, inhibits cytokine secretion and blocks proliferation of different human breast cancer cell lines with comparably low immunotoxicity. Taken together, glidobactin C [85] exactly fulfills the requirement for optimal proteasome inhibition in solid tumors as determined in the study by Weyburne et al. [64].

Furthermore, the recently described non-covalent amide derivate proteasome inhibitors simultaneously target multiple proteasome subunits, and, therefore bear the potential to be effective in solid tumors [89]. Amide derivates targeting the $\beta 5 \mathrm{i}$ and $\beta 2 \mathrm{i}$ have been shown to induce cell cycle arrest in multiple myeloma MM.1R cells [90].

\section{Immunoproteasome co-inhibition in autoimmunity}

ONX 0914 (formerly called PR-957) was the first immunoproteasome inhibitor for which an ameliorating effect in preclinical models of autoimmune diseases could be demonstrated [20]. In two different mouse models of rheumatoid arthritis, collagen antibody-induced arthritis and collagen-induced arthritis, immunoproteasome inhibition strongly reduced disease symptoms. These effects were attributed to reduced inflammatory cytokine secretion and impeded Th17 differentiation. In a model for type I diabetes, ONX 0914 reduced blood glucose levels, probably due to alterations in MHC-I presentation [20]. In a human leukemia cell line, which expresses both forms of the proteasome, ONX 0914 was shown to be 20 - to 40 -fold more selective for LMP7 over the next most sensitive sites, $\beta 5$ or LMP2. Furthermore, in human peripheral blood mononuclear cells (PBMCs), in which standard proteasome subunits are barely expressed, ONX 0914 at concentrations $<100 \mathrm{nM}$ inhibited LMP7 activity by $>80 \%$ with minimal inhibition of LMP2 or MECL-1. However, higher concentrations resulted in a substantial inhibition of LMP2 and MECL-1. In order to demonstrate specificity of ONX 0914, LMP7-deficient cells were used in this study [20]. In contrast to wild-type cells, no reduction in cytokine secretion and MHC-I surface expression could be observed under ONX 0914 inhibition in cells lacking LMP7. Therefore, the authors concluded that the observed effects in this study were LMP7-specific. In vivo, mice were treated with 2,6 , or $10 \mathrm{mg} / \mathrm{kg}$ body weight. Inhibition at $2 \mathrm{mg} / \mathrm{kg}$ was sufficient to block disease progression. However, the subunit specificity in vivo at the used concentrations was not reported in this study. In future studies, ONX 0914 was used in vitro at $200-300 \mathrm{nM}$ and in vivo at $10-20 \mathrm{mg} / \mathrm{kg}[21,22,29,91]$.

During a medicinal chemistry effort focused on the discovery of inhibitors with exclusive selectivity for LMP7, PRN1126 (Fig. 1i) was developed at the pharmaceutical company Principia Biopharma [92]. PRN1126 is a reversible covalent inhibitor of LMP7, covalently anchoring to its peptide cleavage site via reversible binding to Cys 48 on LMP7. In vitro assays showed that PRN1126 was 13 -fold and 30 -fold more selective for mouse and human LMP7 over $\beta 5 \mathrm{c}$, respectively. No selectivity for other standard or immunoproteasome subunits could be observed. Hence, PRN1126 can be considered LMP7-specific at the applied concentrations. However, in contrast to the previously used LMP7 inhibitor ONX 0914, PRN1126 could not reduce MHC-I surface expression on splenocytes, had no effect on IL- 6 secretion by lipopolysaccharide (LPS)-stimulated mouse splenocytes and human PBMCs. Moreover, it did not affect Th17 differentiation and could neither ameliorate dextran sodium sulfate (DSS)-induced colitis nor experimental autoimmune encephalomyelitis (EAE) [92]. To elaborate the difference between ONX 0914 and PRN1126, the specificity profile of the two inhibitors was compared. Studies with fluorogenic proteasome activity substrates and electrophoretic mobility shifts of immunoproteasome subunits revealed that ONX 0914 significantly inhibited both LMP2 and LMP7 at concentrations above $100 \mathrm{nM}$ when cells were incubated with this irreversible epoxyketone inhibitor for longer time periods, whereas PRN1126 remained highly selective for LMP7 and did not inhibit LMP2. It had already been shown that LMP2 inhibition alone had no effect on cytokine secretion and autoimmunity [24, 93]. Therefore, it was hypothesized that inhibition of both LMP7 and LMP2 might be required to induce broad anti-inflammatory effects in vitro and in vivo. A combination of PRN1126 and the well-characterized LMP2specific inhibitors LU-001i (Fig. 1j) [24, 94] or ML604440 (Fig. 1k) [95] were used to investigate this hypothesis. Indeed, it was found that a co-inhibition of both LMP2 and LMP7 is required to reduce MHC-I surface expression on splenocytes, to decrease IL-6 secretion, to impair Th17 differentiation, and to ameliorate experimental colitis and EAE [92] (Fig. 3).

A similar study by Johnson et al. reached the same conclusion [96]. In this study, a library of immunoproteasome subunit-specific inhibitors was employed to probe the role of individual subunits in regulation of cytokine secretion and inflammation. Compared to ONX 0914, selective 


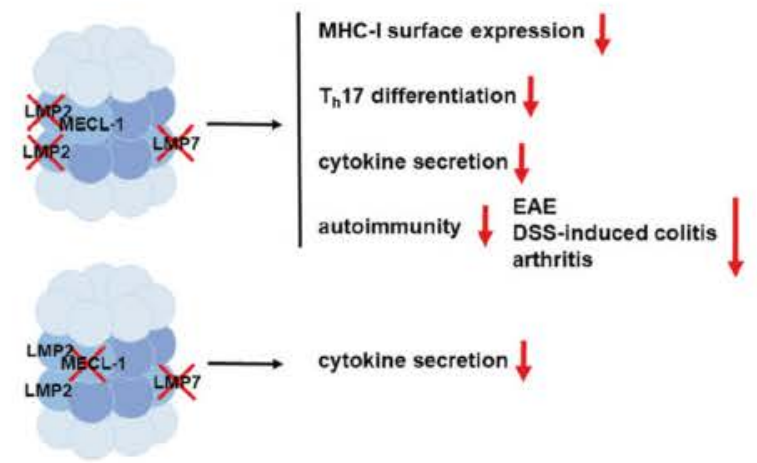

Fig. 3 Co-inhibition in autoimmunity. Co-inhibition of $20 \mathrm{~S}$ immunoproteasome subunits LMP2 and LMP7 (upper panel) reduces MHCI surface expression, impairs Th17 differentiation, decreases cytokine secretion, and ameliorates different autoimmune diseases $[92,96]$. Coinhibition of $20 \mathrm{~S}$ immunoproteasome subunits MECL-1 and LMP7 (lower panel) reduces cytokine secretion [96]

single-site LMP2 (KZR-504; (Fig. 11)), MECL-1 (compound 10;[96] (Fig. 1m)), and LMP7 (compound 8; [96] (Fig. 1n)) inhibitors insufficiently reduced cytokine expression in LPS or T cell receptor stimulated human leukocytes. Since the design of a cross-species selective MECL-1 inhibitor proved to be difficult, an analysis of MECL-1 in mouse disease models was precluded. Instead, LMP7 and LMP2 selective inhibitors were used to explore the therapeutic effect in active collagen antibody-induced arthritis, a mouse model of inflammatory arthritis. Singleagent treatment of diseased mice had a negligible impact on disease progression, indicating that individual subunit inhibition is insufficient to suppress inflammation in vivo. However, applying a combination of LMP7 with either MECL-1 or LMP2 inhibitors in vitro achieved an optimal cytokine inhibition profile. In vivo, dual LMP7 and LMP2 inhibition was therapeutically effective in collagen antibody-induced arthritis (Fig. 3). Interestingly, ONX 0914 achieved activity in a mouse arthritis model via complete LMP7 inhibition and $40 \%$ LMP2 inhibition, suggesting that only partial inhibition of a secondary immunoproteasome subunit is required for a multi-cytokine inhibitory effect. Such a dual proteasome inhibition profile is a hallmark of the immunoproteasome inhibitor KZR-616 (Fig. 10) [96], developed by Kezar Life Sciences, which proved to have a favorable safety profile in healthy humans and is now in a phase 2 clinical trial for treatment of the severe autoimmune disease lupus nephritis [97-99].

Why has the requirement for dual proteasome inhibition for regulating inflammation not been discovered previously? The original publication describing ONX 0914 showed an LMP2 inhibition by ONX 0914 of $\sim 35 \%$ at $200 \mathrm{nM}$ and $75 \%$ at $500 \mathrm{nM}$. This was considered not to be crucial for the observed immunological effects since no influence of ONX 0914 on MHC-I surface expression and cytokine secretion could be observed with LMP7-deficient splenocytes. However, LMP7-deficient mice barely incorporate LMP2 and MELC-1 into immunoproteasomes [100]. Therefore, LMP7-deficient cells can only be used to detect non-immunoproteasome related off-target effects. Furthermore, the crystal structure of ONX 0914-soaked immunoproteasome supported the view of LMP7 selectivity [1]. Although the hydrophobicity of the substrate-specificity pockets of LMP2 supports ONX 0914 binding, atomic distances indicate that Phe 31 creates a steric barrier to the P1 phenyl moiety of ONX 0914. Hence, ONX 0914 was assumed to bind only against significant repulsive forces mirrored in an unfavorable orientation of Phe 31 toward the carbonyl oxygen of Asp32 in LMP2.

These new insights $[92,96]$ will allow the design of new generations of immunoproteasome inhibitors simultaneously targeting LMP2 and LMP7 and possessing optimal therapeutic efficacy for the treatment of autoimmunity. The inhibitor LU-005i (Fig. 1p) fulfills the requirements developed in the study by Basler et al. and Johnson et al. [92, 96]. In a structure-based design approach to obtain proteasome inhibitors with considerably improved selectivity for $\beta 5$ i over $\beta 5 c$ and $\beta 2 i$ over $\beta 2 c$ LU-005i was found [94]. LU-005i is an effective inhibitor of human and mouse MECL-1, LMP2, and LMP7 with at least tenfold selectivity over $\beta 2 \mathrm{c}, \beta 1 \mathrm{c}$, and $\beta 5 \mathrm{c}$ and, therefore, can be considered an immunoproteasomeselective inhibitor targeting all active sites of the immunoproteasome [24]. Treatment of splenocytes with LU-005i reduced MHC-I surface expression only in wild-type cells but not in LMP7-deficient cell, which barely express immunoproteasomes [100], demonstrating that LU-005i is immunoproteasome-selective. LU-005i treatment of endotoxin- or $\mathrm{T}$ cell receptor stimulated mouse splenocytes strongly reduced IL- 6 or IFN- $\gamma$ secretion as well as IL-6 and IL-23 production from LPS-stimulated human PBMCs [24]. Differentiation of naive $\mathrm{T}$ cells to Th17 cells under Th17polarizing conditions was impaired in LU-005i treated cells. LU-005i was also active in vivo in DSS-induced colitis. Treatment of mice with LU-005i in this colitis model resulted in reduced body weight loss, disease activity index, colon length shortening, cytokine expression in the colon, and histological scores compared to vehicle-treated mice. This study confirms that multiple immunoproteasome subunits have to be targeted and that the immunoproteasome is an attractive drug target in inflammatory diseases.

\section{Proteasome inhibition in transplantation. Do we need co-inhibition?}

Organ transplantation has overcome major technical limitations to become the success it is today. Allogeneic organs 
are acutely rejected in the absence of pharmacological immunosuppression. Current immunosuppressive therapies target $\mathrm{T}$ cells nonspecifically and have to be taken lifelong, leaving patients more susceptible to infections and cancers, in addition to having toxic off-target effects. Chronic antibody-mediated rejection is a leading cause of kidney allograft failure years after transplantation. Currently, suitable pharmacological agents for the suppression of chronic antibody-mediated rejection are lacking. Bortezomib inhibits the chronic active antibody-mediated rejection in experimental renal transplantation in the rat [101]. In humans, several smaller studies have suggested efficacy of the proteasome inhibitor bortezomib in preventing antibody-mediated kidney transplant rejection in humans (summarized in [102]). However, a randomized placebocontrolled trial of bortezomib in late antibody-mediated kidney transplant rejection failed to show significant differences between bortezomib- $(n=21)$ and placebo- $(n=$ 23 ) treated groups [16]. The immunoproteasome inhibitor ONX 0914 impeded the chronic rejection of kidneys transplanted from Fischer to allogeneic Lewis rats [46] (summarized in [102]). Chronic nephropathy was ameliorated and renal allograft function preserved, enabling longterm survival of recipient rats. Alloantibodies attacking the transplanted organ are a major driver for rejection of transplanted kidneys. Proteasome inhibitors have been rather successful in treating antibody-driven diseases in preclinical models $[29,103-105]$ and in small clinical trials $[12,13,106]$. However, immunoproteasome inhibitors are preferred over broad-spectrum proteasome inhibitors to treat antibody-mediated diseases since immunoproteasomes are mainly expressed in hematopoietic cells and, therefore, have fewer toxic side effects. Plasma cells are the main producers of alloantibodies. The success of proteasome inhibitors in suppressing antibody-mediated diseases is probably due to the fact that plasma cells need a high proteasome capacity to degrade misfolded antibody chains. Hence, proteasome inhibition leads to the induction of the unfolded protein response and ultimately to the induction of apoptosis. Indeed, in a rat kidney transplantation model it was shown that immunoproteasome inhibition with ONX 0914 induced plasma cell apoptosis and preserved kidney allografts by activating the unfolded protein response and suppressing plasma cell survival factors [47]. Plasma cells isolated from diseased rats showed high expression of LMP2 and LMP7, although standard proteasome subunits were readily detectable. ONX 0914 treatment induced accumulation of protein-ubiquitin-conjugates in plasma cells, indicating that the proteasome capacity is exceeded. As evidenced by upregulation of central downstream molecules of inositolrequiring enzyme la and protein kinase RNA-like ER kinase signaling like $\mathrm{X}$-box binding protein-1, activating transcription factor 4 , and C/EBP homologous protein, the unfolded protein response was activated in these cells. This ultimately resulted in enhanced caspase- 3 cleavage and apoptosis of plasma cells. Is an inhibition of more than one immunoproteasome subunit required to be effective in transplantation? It has been shown that for cytokine secretion and $\mathrm{T}$ helper cell differentiation a co-inhibition of LMP7 and LMP2 or MECL-1 is required [92, 96]. Since such processes also play a role in transplant rejection one can assume that co-inhibition is also required to suppress these processes in order to preserve allografts. Is coinhibition also required to kill antibody producing plasma cells in transplantation? Investigation on immunoproteasome inhibition in rat kidney transplantation has been performed with ONX 0914 [46, 47], which inhibits both LMP7 and to a certain degree LMP2. In the studies by Li et al., LMP7 was inhibited more than $80 \%$ in bone marrow and spleen, whereas $\beta 5 \mathrm{c}$ activity was barely impaired [46]. Although the degree of LMP2 inhibition was not addressed in these studies, one can assume that LMP2 in rats is similarly affected as in mice [92]. Due to the limitations in available cell numbers of plasma cells the determination of proteasome inhibition in these cells remains challenging. Multiple myeloma cells are degenerated neoplastic plasma cells. Therefore, proteasome inhibition-induced cytotoxicity in plasma cells and multiple myeloma cells should be rather similar. Besse et al. demonstrate that proteasome inhibitors targeting $\beta 5$ subunit are cytotoxic only when $\beta 1$ or $\beta 2$ is coinhibited [52]. However, the selective $\beta 2 / \beta 5$ inhibition of both standard and immunoproteasome is the most cytotoxic. Therefore, one can assume that immunoproteasome inhibitors have to co-inhibit $\beta 5 \mathrm{i}$ and another immunoproteasome subunit to prevent antibody-mediated rejection in organ transplantation. However, experiments combining sitespecific immunoproteasome inhibitors in kidney transplantation experiments remain to be performed.

Immunoproteasome inhibition in transplantation has also been performed in a preclinical heart transplant mouse model [17]. In this study, the novel LMP7-selective inhibitor DPLG3 (Fig. 1q) was used. DPLG3 (IC50 for LMP7 of $4.4 \mathrm{nM}$ ) is a non-covalent reversibly acting N,C-capped dipeptide inhibitor of LMP7 that has a 1000 -fold selectivity over the standard subunit $\beta 5 \mathrm{c}$ and shows $<50 \%$ inhibition of $\beta 1 \mathrm{i}, \beta 2 \mathrm{c}, \beta 2 \mathrm{i}$, and $\beta 2 \mathrm{c}$ at $33.3 \mu \mathrm{M}$. No cytotoxic activity of DPLG3 was observed in human PBMCs or mouse bone marrow-derived macrophages. In vitro, DPLG3 inhibited secretion of IFN- $\alpha$ and IP-10 by CpG-activated PBMCs, blocked proliferation of $\mathrm{T}$ cells, and reduced activation of human plasmacytoid dendritic cells. In vivo, Sula Karecci et al. used a stringent preclinical heart transplant mouse model in which BALB/c hearts are transplanted into fully allogeneic C57BL/6 recipients. C57BL/6 recipients were treated with DPLG3 ( $25 \mathrm{mg} / \mathrm{kg}$, i.p., per day) for 14-days beginning on the day of transplantation. Although the survival of the allograft 
was significantly prolonged compared with vehicle-treated recipients (median survival time, 13 vs. 7 days) the transplanted heart was finally rejected. Co-application of DPLG3 with an anti-CTLA4 antibody in different treatment regimens strongly increased the graft survival time. Why is a coinhibition of different immunoproteasome subunits not required in this transplantation model? In contrast to the kidney transplantation model $[46,47]$, in which rejection is mediated by alloantibodies within weeks, rejection of transplanted hearts occurs within days and is mainly mediated by $\mathrm{T}$ cells. In vitro, DPLG3 was used in the low $\mu \mathrm{M}$ range, a concentration which should, according to the reported IC50 values, barely affect LMP2 or MECL-1. In vivo, the degree of immunoproteasome subunit inhibition in hearts or relevant cell types was not reported. Hence, it remains unclear whether co-inhibition of other immunoproteasome subunits is required in this heart transplantation model. Experiments using LMP2 or MECL-1 site-specific inhibitors in addition to DPLG3 would clarify whether inhibition of an additional proteasome site can further improve the outcome of heart transplantation.

\section{Cooperation of immunoproteasome subunits for optimal MHC class I cell surface expression}

Co-inhibition of LMP7 and LMP2 was also required to reduce MHC-I surface expression on spleen lymphocytes [92]. LMP2-deficient mice [107] display, in contrast to LMP7-deficient mice [108], no difference in MHC-I surface expression compared to wild-type mice [109]. This indicates, that LMP2 alone is not rate limiting in producing MHC-I ligands. However, as mentioned above, LMP7deficient mice have reduced LMP2 incorporation into mature proteasomes [100]. Experiments using site-specific inhibitors for LMP2 and LMP7 indicate that both subunits together are rate limiting in MHC-I ligand production in steady-state [92]. Mouse MHC-I molecules only accommodate peptides with hydrophobic C-terminal residues. Since both LMP2 and LMP7 contribute to the chymotrypsin-like activity (and thus to the production of ligands with hydrophobic C-terminus) it seems quite obvious that both subunits together contribute to MHC-I ligand production. Nevertheless, it would be of interest to determine the contribution of MECL-1 to MHC-I antigen presentation with site-specific inhibitors.

\section{Concluding remarks}

The reason to target more than one proteasome subunit in multiple myeloma seems rather clear. Proteasome inhibition in multiple myeloma causes a toxic build-up of proteins leading to apoptosis. The more proteasome subunits are targeted the less proteins can be degraded by the proteasome, leading to an accumulation of proteins destined to be degraded. The cell counteracts by the induction of the unfolded protein response and by the expression of newly synthesized $26 \mathrm{~S}$ proteasome components. If the cell does not succeed, apoptosis is induced in proteasome inhibited cells. In diseases which are mediated by antibody producing plasma cells, like chronic rejection of transplanted organs or systemic lupus erythematosus, a similar mechanism induced by proteasome inhibition might underlie. In solid tumors, the threshold to induce apoptosis by proteasome inhibition is probably higher compared to myeloma cells, since the excessive production of antibodies does not occur in solid tumors. Hence, more sites of the proteasome have to be blocked for prolonged periods to reach a similar degree of protein accumulation as observed in myeloma cells. This can be accomplished by combining current clinically approved proteasome inhibitors with additional $\beta 2$-sitespecific inhibitors. In addition, targeting multiple proteasome sites might impede the development of proteasome inhibitor resistant cells, which emerge due to mutations in genes of the targeted proteasome subunits thus preventing proteasome inhibitor binding. However, joint targeting of proteasome sites for longer time periods might increase toxic side effects in proteasome inhibitor treated patients. Therefore, it is necessary to find treatment regimens in which proteasome inhibition in solid tumors is sufficient to induce protein accumulation-induced cell death while retaining low toxicity in non-neoplastic cells. Targeting multiple sites of the immunoproteasome with immunoproteasome-specific inhibitors might be an alternative treatment strategy for solid tumors expressing high levels of immunoproteasomes. Immunoproteasome inhibitors can reach high inhibition rates in tumors without affecting nonneoplastic cells. However, hematopoietic cells, like $\mathrm{CD} 14^{+}$monocytes have been shown to be particular sensitive to immunoproteasome inhibition [3]. Apart from targeting multiple catalytic proteasome subunits additional factors, such as bioavailability (discussed in [110]) contribute to clinical efficacy. Furthermore, immunoproteasome content of target cells varies among tumor type, differentiation state, and patient. Hence, in contrast to autoimmunity, in which target cells (cells derived from the hematopoietic system) mainly express immunoproteasomes, targeting both constitutive and immunoproteasomes might be beneficial for tumors to induce optimal proteasome inhibition capacity in these cells. In order to measure proteasome activity in vitro and in vivo different methods have been applied. These methods encompass, among others, the use of a cocktail of activity-based probes that enables simultaneous gel-based detection of all six catalytic human proteasome subunits [72], assays based on the cleavage of 
proteasome-specific peptides linked to a fluorophore [111], the use of cell permeable fluorescent proteasome substrates [24], a proteasome immunoprecipitation-based assay [112], and the ELISA based ProCISE (proteasome constitutive immunoproteasome assay subunit ELISA) assay [113, 114].

The reason to target multiple active proteasome sites in autoimmunity, apart from antibody-mediated diseases, is not that obvious. Immunoproteasome inhibition impairs cytokine secretion, $\mathrm{T}$ cell activation [2], and $\mathrm{T}$ helper cell differentiation [115]. How does immunoproteasome inhibition affect these processes? Naive $\mathrm{T}$ and $\mathrm{B}$ cells express nearly exclusively immuno- or mixed proteasomes but no standard proteasomes [2]. Activation of B and $\mathrm{T}$ cells treated with ONX 0914 (inhibits LMP7 and LMP2) led to a transient accumulation of ubiquitin protein aggregates which were resolved $20 \mathrm{~h}$ post treatment [2]. T cell receptortriggered activation of $\mathrm{T}$ cells strongly increases the translation rate in T cells [116]. Hence, proteasomes have to be fully active to maintain protein homeostasis in activated $\mathrm{T}$ cells. Indeed, ONX 0914 treatment induced mild proteostasis stress in $\mathrm{T}$ cells, which was dependent on protein neo-synthesis. However, in contrast to MG-132, which inhibits all subunits of the immunoproteasome [117], ONX 0914 did not induce apoptosis in activated $\mathrm{T}$ cells [2]. Hence, in order to block $\mathrm{T}$ cell activation without inducing cell death, only a partial inhibition of the immunoproteasome is required. This is crucial in the treatment for autoimmunity, since in contrast to tumor cells, induction of cell death in immune cells is not intended. Apparently, the reduced proteasome capacity in ONX 0914 treated T cells is resolved via Nrfl-mediated upregulation of standard proteasomes [2]. Interestingly, ONX 0914 treatment of LMP2deficient $\mathrm{T}$ cells only had a minor effect on $\mathrm{T}$ cell activation, indicating that inhibition of both LMP7 and LMP2 is required to reduce $\mathrm{T}$ cell activation. To investigate whether co-inhibition in $\mathrm{T}$ cell activation is indeed required, experiments combining site-specific immunoproteasome inhibitors have to be performed. T cell activation is the first step in Th17 differentiation. Hence, a similar mechanism as described for $\mathrm{T}$ cell activation might also contribute to $\mathrm{T}$ cell differentiation. Taken together, reducing immunoproteasome capacity in activated $\mathrm{T}$ cells leads to a transient proteostasis stress. Whether such a mechanism also exist in vivo, and thereby suppress autoimmunity, remains to be investigated. Furthermore, how immunoproteasome inhibition reduces cytokine secretion in endotoxin stimulated cells, and whether proteostasis stress processes play a role in cytokine secretion remains to be investigated.

Acknowledgements This work was supported by the German Research Foundation (DFG) grants Nr. BA 4199/2-1 to MB and GR 1517/2.4, GR $1517 / 10-2$ and GR $1517 / 27-1$ to MG as well as by the
SFB969 project $\mathrm{C} 01$ and the Else Kröner-Fresenius-Stiftung grant Nr. 2017_A28 to MG.

Author contributions $\mathrm{MB}$ wrote the paper and designed the figures. $M B$ and MG refined the paper.

\section{Compliance with ethical standards}

Conflict of interest Work in our laboratory described in this review was supported by the pharmaceutical companies Kezar Life Sciences, Principia Biopharma, and Takeda Pharmaceuticals.

Publisher's note Springer Nature remains neutral with regard to jurisdictional claims in published maps and institutional affiliations.

\section{References}

1. Huber EM, Basler M, Schwab R, Heinemeyer W, Kirk CJ, Groettrup M, et al. Immuno- and constitutive proteasome crystal structures reveal differences in substrate and inhibitor specificity. Cell. 2012;148:727-38.

2. Schmidt C, Berger T, Groettrup M, Basler M. Immunoproteasome inhibition impairs $\mathrm{T}$ and $\mathrm{B}$ cell activation by restraining ERK signaling and proteostasis. Front Immunol. 2018;9:2386.

3. Basler M, Claus M, Klawitter M, Goebel H, Groettrup M. Immunoproteasome inhibition selectively kills human CD14(+) monocytes and as a result dampens IL-23 secretion. J Immunol. 2019;203:1776-85.

4. Vigneron N, Abi Habib J, Van den Eynde BJ. Learning from the proteasome how to fine-tune cancer immunotherapy. Trends Cancer. 2017;3:726-41.

5. Kisselev AF, van der Linden WA, Overkleeft HS. Proteasome inhibitors: an expanding army attacking a unique target. Chem Biol. 2012;19:99-115.

6. Kisselev AF, Groettrup M. Subunit specific inhibitors of proteasomes and their potential for immunomodulation. Curr Opin Chem Biol. 2014;23C:16-22.

7. Ettari R, Zappala M, Grasso S, Musolino C, Innao V, Allegra A. Immunoproteasome-selective and non-selective inhibitors: a promising approach for the treatment of multiple myeloma. Pharmacol Ther. 2018;182:176-92.

8. Sherman DJ, Li J. Proteasome inhibitors: harnessing proteostasis to combat disease. Molecules, 2020;25:671.

9. Adams J, Palombella VJ, Sausville EA, Johnson J, Destree A, Lazarus DD, et al. Proteasome inhibitors: a novel class of potent and effective antitumor agents. Cancer Res. 1999;59:2615-22.

10. Kuhn DJ, Chen Q, Voorhees PM, Strader JS, Shenk KD, Sun $\mathrm{CM}$, et al. Potent activity of carfilzomib, a novel, irreversible inhibitor of the ubiquitin-proteasome pathway, against preclinical models of multiple myeloma. Blood. 2007;1 10:3281-90.

11. Kupperman E, Lee EC, Cao Y, Bannerman B, Fitzgerald M, Berger A, et al. Evaluation of the proteasome inhibitor MLN9708 in preclinical models of human cancer. Cancer Res. 2010;70:1970-80.

12. Alexander T, Cheng Q, Klotsche J, Khodadadi L. Waka A. Biesen R, et al. Proteasome inhibition with bortezomib induces a therapeutically relevant depletion of plasma cells in SLE but does not target their precursors. Eur J Immunol. 2018:48:1573-9.

13. van Dam LS, Osmani Z, Kamerling SWA, Kraaij T, Bakker JA, Scherer HU, et al. A reverse translational study on the effect of rituximab, rituximab plus belimumab, or bortezomib on the 
humoral autoimmune response in SLE. Rheumatology. 2020. https://doi.org/10.1093/rheumatology/kez623.

14. Everly MJ, Everly JJ, Susskind B, Brailey P, Arend LJ, Alloway RR, et al. Bortezomib provides effective therapy for antibodyand cell-mediated acute rejection. Transplantation. 2008;86:1754-61

15. Pearl $\mathrm{MH}$, Nayak AB, Ettenger RB, Puliyanda D, Palma Diaz MF, Zhang Q, et al. Bortezomib may stabilize pediatric renal transplant recipients with antibody-mediated rejection. Pediatr Nephrol. 2016:31:1341-8.

16. Eskandary F, Regele H, Baumann L, Bond G, Kozakowski N. Wahrmann M, et al. A randomized trial of bortezomib in late antibody-mediated kidney transplant rejection. J Am Soc Nephrol. 2018;29:591-605.

17. Sula Karreci E, Fan H, Uehara M, Mihali AB, Singh PK, Kurd AT, et al. Brief treatment with a highly selective immunoproteasome inhibitor promotes long-term cardiac allograft acceptance in mice. Proc Natl Acad Sci USA. 2016;113:E8425-E8432.

18. Santos RLA, Bai L, Singh PK, Murakami N, Fan H, Zhan W, et al. Structure of human immunoproteasome with a reversible and noncompetitive inhibitor that selectively inhibits activated lymphocytes. Nat Commun. 2017;8:1692.

19. Chen S, Kammerl IE, Vosyka O, Baumann T, Yu Y, Wu Y, et al. Immunoproteasome dysfunction augments alternative polarization of alveolar macrophages. Cell Death Differ. 2016:23:1026-37.

20. Muchamuel T, Basler M, Aujay MA, Suzuki E, Kalim KW, Lauer C, et al. A selective inhibitor of the immunoproteasome subunit LMP7 blocks cytokine production and attenuates progression of experimental arthritis. Nat Med. 2009;15:781-7.

21. Basler M, Dajee M, Moll C, Groettrup M, Kirk CJ. Prevention of experimental colitis by a selective inhibitor of the immunoproteasome. J Immunol. 2010;185:634-41.

22. Basler M, Mundt S, Muchamuel T, Moll C, Jiang J, Groettrup M, et al. Inhibition of the immunoproteasome ameliorates experimental autoimmune encephalomyelitis. EMBO Mol Med. $2014 ; 6: 226-38$

23. Farini A, Sitzia C, Cassani B, Cassinelli L, Rigoni R, Colleoni F, et al. Therapeutic potential of immunoproteasome inhibition in duchenne muscular dystrophy. Mol Ther. 2016;24:1898-912.

24. Basler M, Maurits E, de Bruin G, Koemer J, Overkleeft HS, Groettrup M. Amelioration of autoimmunity with an inhibitor selectively targeting all active centres of the immunoproteasome. Br J Pharmacol. 2018;175:38-52

25. Guo Y, Chen X, Li D, Liu H, Ding Y, Han R, et al. PR-957 mediates neuroprotection by inhibiting Th17 differentiation and modulating cytokine production in a mouse model of ischaemic stroke. Clin Exp Immunol. 2018;193:194-206.

26. Vachharajani N, Joeris T, Luu M, Hartmann S, Pautz S, Jenike E, et al. Prevention of colitis-associated cancer by selective targeting of immunoproteasome subunit LMP7. Oncotarget. 2017:8:50447-59.

27. Kalim KW, Basler M, Kirk CJ, Groettrup M. Immunoproteasome subunit LMP7 deficiency and inhibition suppresses Thl and Th17 but enhances regulatory $\mathrm{T}$ cell differentiation. J Immunol. 2012;189:4182-93.

28. Xiao F, Lin X, Tian J, Wang X, Chen Q, Rui K, et al. Proteasome inhibition suppresses Th17 cell generation and ameliorates autoimmune development in experimental Sjogren's syndrome. Cell Mol Immunol. 2017;14:924-34.

29. Ichikawa HT, Conley T, Muchamuel T, Jiang J, Lee S, Owen T, et al. Novel proteasome inhibitors have a beneficial effect in murine lupus via the dual inhibition of type $\mathrm{i}$ interferon and autoantibody secreting cells. Arthritis Rheum. 2012;64:493-503.

30. Nagayama Y, Nakahara M, Shimamura M, Horie I, Arima K, Abiru N. Prophylactic and therapeutic efficacies of a selective inhibitor of the immunoproteasome for Hashimoto's thyroiditis, but not for Graves' hyperthyroidism, in mice. Clin Exp Immunol. 2012;168:268-73

31. Liu H, Wan C, Ding Y, Han R, He Y, Xiao J, et al. PR-957, a selective inhibitor of immunoproteasome subunit low-MW polypeptide 7 , attenuates experimental autoimmune neuritis by suppressing Th17 cell differentiation and regulating cytokine production. FASEB J. 2017;31:1756-66.

32. Liu RT, Zhang P, Yang CL, Pang Y, Zhang M, Zhang N, et al. ONX-0914, a selective inhibitor of immunoproteasome, ameliorates experimental autoimmune myasthenia gravis by modulating humoral response. J Neuroimmunol. 2017;311:71-78.

33. Moallemian R, Rehman AU, Zhao N, Wang H, Chen H, Lin G, et al. Immunoproteasome inhibitor DPLG3 attenuates experimental colitis by restraining NF- $\mathrm{BB}$ activation. Biochem Pharmacol, 2020;177; 113964.

34. Kremer M, Henn A, Kolb C, Basler M, Moebius J, Guillaume B, et al. Reduced immunoproteasome formation and accumulation of immunoproteasomal precursors in the brains of lymphocytic choriomeningitis virus-infected mice. J Immunol. 2010;185:5549-60.

35. Mundt S, Engelhardt B, Kirk CJ, Groettrup M, Basler M. Inhibition and deficiency of the immunoproteasome subunit LMP7 attenuates LCMV-induced meningitis. Eur J Immunol. 2016;46:104-13.

36. Koerner J, Brunner T, Groettrup M. Inhibition and deficiency of the immunoproteasome subunit LMP7 suppress the development and progression of colorectal carcinoma in mice. Oncotarget. 2017:8:50873-88.

37. Chen $X$, Zhang X, Chen T, Jiang X, Wang X, Lei H, et al. Inhibition of immunoproteasome promotes angiogenesis via enhancing hypoxia-inducible factor-1alpha abundance in rats following focal cerebral ischaemia. Brain Behav Immun. 2018;73:167-79.

38. Althof N, Goetzke CC, Kespohl M, Voss K, Heuser A, Pinkert S, et al. The immunoproteasome-specific inhibitor ONX 0914 reverses susceptibility to acute viral myocarditis. EMBO Mol Med. 2018;10:200-18

39. Zhang XZ, Han F, Ding CG, Dou M, Wang YX, Xue WJ, et al. Different roles of bortezomib and ONX 0914 in acute kidney injury. Int Immunopharmacol. 2020;82:106259.

40. Liong S, Lim R, Nguyen-Ngo C, Barker G, Parkington HC, Lappas M. The immunoproteasome inhibitor ONX-0914 regulates inflammation and expression of contraction associated proteins in myometrium. Eur J Immunol. 2018;48:1350-63.

41. Li FD, Nie H, Tian C, Wang HX, Sun BH, Ren HL, et al. Ablation and inhibition of the immunoproteasome catalytic subunit LMP7 attenuate experimental abdominal aortic aneurysm formation in mice. J Immunol. 2019;202:1176-85.

42. Liao J, Xie Y, Lin Q, Yang X, An X, Xia Y, et al. Immunoproteasome subunit $\beta 5 \mathrm{i}$ regulates diet-induced atherosclerosis through altering MERTK-mediated efferocytosis in Apoe knockout mice. J Pathol. 2020;250:275-87.

43. Cao HJ, Fang J, Zhang YL, Zou LX, Han X, Yang J, et al. Genetic ablation and pharmacological inhibition of immunosubunit beta5i attenuates cardiac remodeling in deoxycorticosterone-acetate (DOCA)-salt hypertensive mice. J Mol Cell Cardiol. 2019;137:34-45.

44. Yeo IJ, Lee MJ, Baek A, Miller Z, Bhattarai D, Baek YM, et al. A dual inhibitor of the proteasome catalytic subunits LMP2 and $\mathrm{Y}$ attenuates disease progression in mouse models of Alzheimer's disease. Sci Rep. 2019;9:18393.

45. Bhattarai D, Lee MJ, Baek A, Yeo IJ, Miller Z, Baek YM, et al. LMP2 inhibitors as a potential treatment for Alzheimer's Disease. J Med Chem. 2020;63:3763-83.

46. Li J, Basler M, Alvarez G, Brunner T, Kirk CJ, Groettrup M. Immunoproteasome inhibition prevents chronic antibody- 
mediated allograft rejection in renal transplantation. Kidney Int. 2018;93:670-80.

47. Li J, Koerner J, Basler M, Brunner T, Kirk CJ, Groettrup M. Immunoproteasome inhibition induces plasma cell apoptosis and preserves kidney allografts by activating the unfolded protein response and suppressing plasma cell survival factors. Kidney Int. 2019;95:611-23.

48. von Brzezinski L, Saring P, Landgraf P, Cammann C, Seifert U, Dieterich DC. Low neurotoxicity of ONX-0914 supports the idea of specific immunoproteasome inhibition as a side-effect-limiting, therapeutic strategy. Eur J Microbiol Immunol. 2017:7:234 45.

49. Cenci S, Oliva L, Cerruti F, Milan E, Bianchi G, Raule M, et al. Pivotal advance: protein synthesis modulates responsiveness of differentiating and malignant plasma cells to proteasome inhibitors. J Leukoc Biol. 2012;92:921-31.

50. Heinemeyer W, Gruhler A, Mohrle V, Mahe Y, Wolf DH. PRE2, highly homologous to the human major histocompatibility complex-linked RING10 gene, codes for a yeast proteasome subunit necessary for chrymotryptic activity and degradation of ubiquitinated proteins. J Biol Chem. 1993;268:5115-20.

51. Arendt CS, Hochstrasser M. Identification of the yeast 20S proteasome catalytic centers and subunit interactions required for active-site formation. Proc Natl Acad Sci USA. 1997;94:7156-61.

52. Besse A, Besse L, Kraus M, Mendez-Lopez M, Bader J, Xin BT, et al. Proteasome inhibition in multiple myeloma: head-to-head comparison of currently available proteasome inhibitors. Cell Chem Biol. 2019;26:340-51. e3.

53. Kisselev AF, Callard A, Goldberg AL. Importance of the different proteolytic sites of the proteasome and the efficacy of inhibitors varies with the protein substrate. J Biol Chem. 2006:281:8582-90.

54. Oberdorf J, Carlson EJ, Skach WR. Redundancy of mammalian proteasome beta subunit function during endoplasmic reticulum associated degradation. Biochemistry. 2001;40:13397-405.

55. Britton M, Lucas MM, Downey SL, Screen M, Pletnev AA, Verdoes M, et al. Selective inhibitor of proteasome's caspaselike sites sensitizes cells to specific inhibition of chymotrypsinlike sites. Chem Biol. 2009;16:1278-89.

56. Mirabella AC, Pletnev AA, Downey SL, Florea BI, Shabaneh TB, Britton M, et al. Specific cell-permeable inhibitor of proteasome trypsin-like sites selectively sensitizes myeloma cells to bortezomib and carfilzomib. Chem Biol. 2011;18:608-18.

57. Geurink PP, van der Linden WA, Mirabella AC, Gallastegui N, de Bruin G, Blom AE, et al. Incorporation of non-natural amino acids improves cell permeability and potency of specific inhibitors of proteasome trypsin-like sites. J Med Chem. 2013:56:1262-75.

58. Kraus M, Bader J, Geurink PP, Weyburne ES, Mirabella AC, Silzle T, et al. The novel beta2-selective proteasome inhibitor LU-102 synergizes with bortezomib and carfilzomib to overcome proteasome inhibitor resistance of myeloma cells. Haematologica. 2015;100:1350-60.

59. Altun M, Galardy PJ, Shringarpure R, Hideshima T, LeBlanc R, Anderson KC, et al. Effects of PS-341 on the activity and composition of proteasomes in multiple myeloma cells. Cancer Res. 2005;65:7896-901.

60. Demo SD, Kirk CJ, Aujay MA, Buchholz TJ, Dajee M, Ho MN et al. Antitumor activity of PR-171, a novel irreversible inhibitor of the proteasome. Cancer Res. 2007;67:6383-91.

61. Lee SJ, Levitsky K, Parlati F, Bennett MK, Arastu-Kapur S, Kellerman L, et al. Clinical activity of carfilzomib correlates with inhibition of multiple proteasome subunits: application of a novel pharmacodynamic assay. Br J Haematol. 2016;173:884-95.
62. Huang Z, Wu Y, Zhou X, Xu J, Zhu W, Shu Y, et al. Efficacy of therapy with bortezomib in solid tumors: a review based on 32 clinical trials. Future Oncol. 2014;10:1795-807.

63. Trinh XB, Sas L, Van Laere SJ, Prove A, Deleu I, Rasschaert M, et al. A phase II study of the combination of endocrine treatment and bortezomib in patients with endocrine-resistant metastatic breast cancer. Oncol Rep. 2012;27:657-63.

64. Weyburne ES, Wilkins OM, Sha Z, Williams DA, Pletnev AA, de Bruin G, et al. Inhibition of the proteasome beta2 site sensitizes triple-negative breast cancer cells to beta5 inhibitors and suppresses Nrfl activation. Cell Chem Biol. 2017;24:218-30.

65. Yang $\mathrm{CH}$, Gonzalez-Angulo AM, Reuben JM, Booser DJ, Pusztai L, Krishnamurthy S, et al. Bortezomib (VELCADE) in metastatic breast cancer: pharmacodynamics, biological effects, and prediction of clinical benefits. Ann Oncol. 2006:17:813-7.

66. Steffen J, Seeger M, Koch A, Kruger E. Proteasomal degradation is transcriptionally controlled by TCF11 via an ERAD-dependent feedback loop. Mol Cell. 2010;40:147-58.

67. Radhakrishnan SK, Lee CS, Young P, Beskow A, Chan JY, Deshaies RJ. Transcription factor Nrf1 mediates the proteasome recovery pathway after proteasome inhibition in mammalian cells. Mol Cell. 2010;38:17-28.

68. Koizumi S, Irie T, Hirayama S, Sakurai Y, Yashiroda H, Naguro I, et al. The aspartyl protease DDI2 activates Nrfl to compensate for proteasome dysfunction. Elife. 2016;5:e18357.

69. Lehrbach NJ, Ruvkun G. Proteasome dysfunction triggers activation of SKN-1A/Nrf1 by the aspartic protease DDI-1. Elife. 2016:5:e17721.

70. Sha Z, Goldberg AL. Proteasome-mediated processing of $\mathrm{Nrfl}$ is essential for coordinate induction of all proteasome subunits and p97. Curr Biol. 2014;24:1573-83.

71. Sha Z, Goldberg AL, et al. Complete inhibition of the proteasome reduces new proteasome production by causing $\mathrm{Nrfl}$ aggregation. Curr Biol. 2016;26:R836-R837.

72. de Bruin G, Xin BT, Kraus M, van der Stelt M, van der Marel GA, Kisselev AF, et al. A set of activity-based probes to visualize human (Immuno)proteasome activities. Angew Chem Int Ed Engl. 2016;55:4199-203.

73. Feling RH, Buchanan GO, Mincer TJ, Kauffman CA, Jensen PR, Fenical W. Salinosporamide A: a highly cytotoxic proteasome inhibitor from a novel microbial source, a marine bacterium of the new genus salinospora. Angew Chem Int Ed Engl. 2003;42:355-7.

74. Levin N, Spencer A, Harrison SJ, Chauhan D, Burrows FJ, Anderson $\mathrm{KC}$, et al. Marizomib irreversibly inhibits proteasome to overcome compensatory hyperactivation in multiple myeloma and solid tumour patients. Br J Haematol. 2016:174:711-20.

75. Di K, Lloyd GK, Abraham V, MacLaren A, Burrows FJ, Desjardins A, et al. Marizomib activity as a single agent in malignant gliomas: ability to cross the blood-brain barrier. Neuro Oncol. 2016;18:840-8.

76. Richardson PG, Zimmerman TM, Hofmeister CC, Talpaz M, Chanan-Khan AA, Kaufman JL, et al. Phase 1 study of marizomib in relapsed or relapsed and refractory multiple myeloma: NPI-0052-101 Part 1. Blood. 2016;127:2693-700.

77. Harrison SJ, Mainwaring P, Price T, Millward MJ, Padrik P, Underhill CR, et al. Phase I clinical trial of marizomib (NPI0052 ) in patients with advanced malignancies including multiple myeloma: study NPI-0052-102 final results. Clin Cancer Res. 2016;22:4559-66.

78. Badros A, Singh Z, Dhakal B, Kwok Y, MacLaren A, Richardson P, et al. Marizomib for central nervous systemmultiple myeloma. Br J Haematol. 2017;177:221-5.

79. Spencer A, Harrison S, Zonder J, Badros A, Laubach J, Bergin $\mathrm{K}$, et al. A phase 1 clinical trial evaluating marizomib, pomalidomide and low-dose dexamethasone in relapsed and refractory 
multiple myeloma (NPI-0052-107): final study results. $\mathrm{Br} \mathrm{J}$ Haematol. 2018;180:41-51.

80. Baritaki S, Suzuki E, Umezawa K, Spandidos DA, Berenson J, Daniels TR, et al. Inhibition of Yin Yang 1-dependent repressor activity of DR5 transcription and expression by the novel proteasome inhibitor NPI-0052 contributes to its TRAIL-enhanced apoptosis in cancer cells. J Immunol. 2008;180:6199-210.

81. Sloss CM, Wang F, Liu R, Xia L, Houston M, Ljungman D, et al. Proteasome inhibition activates epidermal growth factor receptor (EGFR) and EGFR-independent mitogenic kinase signaling pathways in pancreatic cancer cells. Clin Cancer Res. 2008; 14:5116-23.

82. Vlashi E, Mattes M, Lagadec C, Donna LD, Phillips TM, Nikolay P, et al. Differential effects of the proteasome inhibitor NPI-0052 against glioma cells. Transl Oncol. 2010;3:50-5.

83. Bullova P, Cougnoux A, Marzouca G, Kopacek J, Pacak K. Bortezomib alone and in combination with salinosporamid A induces apoptosis and promotes pheochromocytoma cell death in vitro and in female nude mice. Endocrinology. 2017; 158:3097-108.

84. Downey-Kopyscinski S, Daily EW, Gautier M, Bhatt A, Florea BI, Mitsiades CS, et al. An inhibitor of proteasome beta2 sites sensitizes myeloma cells to immunoproteasome inhibitors. Blood Adv. 2018;2:2443-51.

85. Pawar A, Basler M, Goebel H, Alvarez Salinas GO, Groettrup M, Bottcher T. Competitive metabolite profiling of natural products reveals subunit specific inhibitors of the $20 \mathrm{~S}$ proteasome. ACS Cent Sci. 2020;6:241-6.

86. Groll M, Schellenberg B, Bachmann AS, Archer CR, Huber R, Powell TK, et al. A plant pathogen virulence factor inhibits the eukaryotic proteasome by a novel mechanism. Nature. 2008;452:755-8

87. Clerc J, Li N, Krahn D, Groll M, Bachmann AS, Florea BI, et al. The natural product hybrid of Syringolin A and Glidobactin A synergizes proteasome inhibition potency with subsite selectivity. Chem Commun. 2011;47:385-7.

88. Stein ML, Beck P, Kaiser M, Dudler R, Becker CF, Groll M One-shot NMR analysis of microbial secretions identifies highly potent proteasome inhibitor. Proc Natl Acad Sci USA 2012;109:18367-71.

89. Ettari R, Cerchia C, Maiorana S, Guccione M, Novellino E, Bitto A, et al. Development of novel amides as noncovalent inhibitors of immunoproteasomes. ChemMedChem. 2019;14:842-52.

90. Ettari R, Pallio G, Pizzino G, Irrera N, Zappala M, Maiorana S, et al. Non-covalent immunoproteasome inhibitors induce cell cycle arrest in multiple myeloma MM.1R cells. J Enzym Inhib Med Chem. 2019;34:1307-13.

91. Basler M, Beck U, Kirk CJ, Groettrup M. The antiviral immune response in mice devoid of immunoproteasome activity. J Immunol. 2011;187:5548-57.

92. Basler M, Lindstrom MM, LaStant JJ, Bradshaw JM, Owens TD, Schmidt C, et al. Co-inhibition of immunoproteasome subunits LMP2 and LMP7 is required to block autoimmunity. EMBO Rep. 2018;19:e46512

93. Johnson HWB, Anderl JL, Bradley EK, Bui J, Jones J, ArastuKapur S, et al. Discovery of highly selective inhibitors of the immunoproteasome low molecular mass polypeptide 2 (LMP2) subunit. ACS Med Chem Lett. 2017;8:413-7.

94. de Bruin G, Huber EM, Xin BT, van Rooden EJ, Al-Ayed K, $\mathrm{Kim} \mathrm{KB}$, et al. Structure-based design of betali or beta5i specific inhibitors of human immunoproteasomes. J Med Chem. 2014;57:6197-209.

95. Basler M, Lauer C, Moebius J, Weber R, Przybylski M, Kisselev $\mathrm{AF}$, et al. Why the structure but not the activity of the immunoproteasome subunit low molecular mass polypeptide 2 rescues antigen presentation. J Immunol. 2012;189:1868-77.
96. Johnson HWB, Lowe E, Anderl JL, Fan A, Muchamuel T, Bowers S, et al. A required immunoproteasome subunit inhibition profile for anti-inflammatory efficacy and clinical candidate KZR-616 ((2S,3R)-N-((S)-3-(cyclopent-1-en-1-yl)-1-((R)-2methyloxiran-2-yl)-1-oxopropan-2 -yl)-3-hydroxy-3-(4-methoxyphenyl)-2-((S)-2-(2-morpholinoacetamido)propanamido)pr openamide). J Med Chem. 2018;61:11127-43.

97. Lickliter J, Bomba D, Anderl J, Fan A, Kirk CJ, Wang J. AB0509 Kzr-616, a selective inhibitor of the immunoproteasome, shows a promising safety and target inhibition profile in a phase i, double-blind, single (SAD) and multiple ascending dose (MAD) study in healthy volunteers. Ann Rheum Dis. 2018;77:1413-4.

98. Furie R, Bomba D, Dall'era M, Prieto M, Anderl J, Wang J, et al. FRI0196 Treatment of systemic lupus erythematosus patients with the immunoproteasome inhibitor KZR-616: results from the first 2 cohorts of an open-label phase 1B dose escalation trial. Ann Rheum Dis. 2019:78:776-7.

99. Furie R, Parikh SV, Maiquez A, Khan A, Moreno O, Soneira M, et al. P130 Treatment of SLE with the immunoproteasome inhibitor KZR-616: results from the first 4 cohorts of the MISSION study, an open-label phase $1 \mathrm{~b}$ dose escalation trial. Lupus Sci Med. 2020;7:A93-A93.

100. De M, Jayarapu K, Elenich L, Monaco JJ, Colbert RA, Griffin TA. Beta 2 subunit propeptides influence cooperative proteasome assembly. J Biol Chem. 2003;278:6153-9.

101. Vogelbacher R, Meister S, Guckel E, Starke C, Wittmann S, Stief A, et al. Bortezomib and sirolimus inhibit the chronic active antibody-mediated rejection in experimental renal transplantation in the rat. Nephrol Dial Transplant. 2010;25:3764-73.

102. Basler M, Li J, Groettrup M. On the role of the immunoproteasome in transplant rejection. Immunogenetics. 2018;71:263-71.

103. Neubert K, Meister S, Moser K, Weisel F, Maseda D, Amann K. et al. The proteasome inhibitor bortezomib depletes plasma cells and protects mice with lupus-like disease from nephritis. Nat Med. 2008; 14:748-55.

104. Ikeda T, Fujii H, Nose M, Kamogawa Y, Shirai T, Shirota Y, et al. Bortezomib treatment induces a higher mortality rate in lupus model mice with a higher disease activity. Arthritis Res Ther. 2017:19:187.

105. Eleftheriadis T, Pissas G, Antoniadi G, Liakopoulos V, Stefanidis I. A comparative analysis between proteasome and immunoproteasome inhibition in cellular and humoral alloimmunity. Int Immunopharmacol. 2017;50:48-54.

106. Alexander T, Sarfert R, Klotsche J, Kuhl AA, Rubbert-Roth A, Lorenz HM, et al. The proteasome inhibitior bortezomib depletes plasma cells and ameliorates clinical manifestations of refractory systemic lupus erythematosus. Ann Rheum Dis. 2015;74:1474-8

107. Van Kaer L, Ashton-Rickardt PG, Eichelberger M, Gaczynska M, Nagashima K, Rock KL, et al. Altered peptidase and viralspecific $\mathrm{T}$ cell response in LMP 2 mutant mice. Immunity. 1994;1:533-41.

108. Fehling HJ, Swat W, Laplace C, Kuhn R, Rajewsky K, Muller U, et al. MHC class I expression in mice lacking the proteasome subunit LMP-7. Science. 1994;265:1234-7.

109. Groettrup M, Kirk CJ, Basler M. Proteasomes in immune cells: more than peptide producers? Nat Rev Immunol. 2010;10:73-8.

110. Thibaudeau TA, Smith DM. A practical review of proteasome pharmacology. Pharmacol Rev. 2019;71:170-97.

111. Reinheckel T, Sitte N, Ullrich O, Kuckelkorn U, Davies KJ, Grune T. Comparative resistance of the $20 \mathrm{~S}$ and $26 \mathrm{~S}$ proteasome to oxidative stress. Biochem J. 1998:335:637-42.

112. Basler M, Groettrup M. Immunoproteasome-specific inhibitors and their application. Methods Mol Biol. 2012;832:391-401. 
113. Parlati F, Lee SJ, Aujay M, Suzuki E, Levitsky K, Lorens JB, et al. Carfilzomib can induce tumor cell death through selective inhibition of the chymotrypsin-like activity of the proteasome. Blood. 2009;114:3439-47.

114. Kirk CJ, Powell SR, Miller EJ. Assessment of cytokinemodulated proteasome activity. Methods Mol Biol. 2014:1172:147-62.

115. Basler M, Kirk CJ, Groettrup M. The immunoproteasome in antigen processing and other immunological functions. Curr Opin Immunol. 2013;25:74-80.

116. Kleijn M, Proud CG. The regulation of protein synthesis and translation factors by $\mathrm{CD} 3$ and $\mathrm{CD} 28$ in human primary $\mathrm{T}$ lymphocytes. BMC Biochem. 2002;3:11.

117. Crawford LJ, Walker B, Ovaa H, Chauhan D, Anderson KC, Morris TC, et al. Comparative selectivity and specificity of the proteasome inhibitors BzLLLCOCHO, PS-341, and MG-132. Cancer Res. 2006;66:6379-86.
118. Bockstahler M, Fischer A, Goetzke CC, Neumaier HL, Sauter M, Kespohl M, et al. Heart-specific immune responses in an animal model of autoimmune-related myocarditis mitigated by an immunoproteasome inhibitor and genetic ablation. Circulation. 2020;141:1885-902.

119. Neumaier HL, Harel S, Klingel K, Kaya Z, Heuser A, Kespohl M, et al. ONX 0914 lacks selectivity for the cardiac immunoproteasome in CoxsackievirusB3 myocarditis of NMRI mice and promotes virus-mediated tissue damage. Cells. 2020;9:1093.

120. Mundt S, Basler M, Buerger S, Engler H, Groettrup M. Inhibiting the immunoproteasome exacerbates the pathogenesis of systemic Candida albicans infection in mice. Sci Rep. 2016:6:19434.

121. McCarthy MK, Malitz DH, Molloy CT, Procario MC, Greiner $\mathrm{KE}$, Zhang L, et al. Interferon-dependent immunoproteasome activity during mouse adenovirus type 1 infection. Virology. 2016:498:57-68. 